\title{
Prologue
}

\section{That I may see and tell}

From the intensive study and analysis of individual poems the thoughtful student will acquire some un-

derstanding of the meaning and form of poetry; but it seems improbable that much real profit is to be derived from that phase of modern criticism which, without respect for tradition, is preoccupied with mere image and pattern, and which, as F. L. Lucas has observed, is overgrown with thickets of jargon and submerged in the swamps of pseudo psychology and fancy metaphysics. The prudent student will rely mainly on that historical approach which unfortunately, as we have just been reminded (The Times Literary Supplement, March 16, 1956), "has recently fallen out of fashion." By no means disparaging the closest scrutiny of poetic form and meaning, I urge that only a patient and thorough investigation of tradition and the historical setting will enable the student to understand fully what Milton means. For in Milton, as perhaps in no other poet, more is meant than meets the ear and the eye of the critic. A true understanding of Milton's poetry depends upon the comprehension of his thought and its relation to an extensive and complex background, literary, intellectual, and spiritual. At this distance of time and in this secular age, no one, however sedulous and resourceful, may hope to become familiar with the entire tradition which is embodied and reflected in the art and thought of this poet, who towers above the rest in thought and art, "In shape and gesture proudly eminent."

It may, however, be possible to isolate and study definite ideas and themes in various poems. In each of the following essays the 
method is much the same: the topic is treated historically in some detail, with full recognition of the contributions of scholars and critics but with emphasis upon interpretations based on the scrutiny of tradition and the contemporary milieu as far as these can be ascertained. The purpose is not to discover sources or to list verbal similarities but rather to trace, as precisely and as thoroughly as possible, the course of specific ideas and themes and their ultimate embodiment or transformation in Milton's poetry. I can honestly say that I have tried to be thorough and accurate; I have attempted to indicate the important stages and documents in each case; and I trust that the conclusions, though not very original, may be accepted as valid.

In these studies all the major poems except Paradise Regained are embraced. In the first the relation of Comus to Jonson's masques is re-examined and an independent critical reappraisal is attempted. In the next the central passage on the clergy in Lycidas is interpreted in the light of Scripture and the Protestant tradition. In the four studies that follow various aspects of the imagery, the ideas, and the structure of Paradise Lost are scrutinized. All the studies except the last are now published for the first time, and the last has been revised. As I have repeatedly stated, my purpose is not to discover specific literary sources of Milton's poetry but to show the relationship of the poetry to tradition or to show how Milton uses certain traditional ideas.

These studies ignore Milton's classical heritage and what has recently been called "the basic classicist meaning of Renaissance humanism." Milton's thorough assimilation of classical culture is of course indisputable. On the other hand, his profound concern with morality and religion warrants the character and the purpose of these studies, which, to be sure, do not pretend to represent all the phases of his intellectual or even his spiritual interests.

However incomplete, this work is the result of some years of study and reflection. In the later stages it was supported by the interest and appreciation of a devoted band of graduate students and especially by Miss Ann Mary Gossman, who is already an accomplished Milton scholar. To Miss Gossman I am especially grateful for "safe convoy" along the "perplex't paths" of the patristic wilderness, "The nodding horror of whose shady brows/Threats the forlorn and wandring Passinger."

It is my hope that these studies will be useful to students and that in style and thought they may not be quite unworthy of the poet viii 


\section{Prologue}

whom for years I have read with unfailing interest; whose life is an inspiration and a challenge; whose poetry has led me and others in this "pendant world," in this dim spot called earth-in this universe once conceived to have been created and to be ruled by God-to believe that the Word received in faith "worketh the health of the soul," to cherish virtue and truth, to appreciate poetry for its form but more for its meaning, and sometimes to see if not to tell

\section{Of things invisible to mortal sight.}

If I should fall into doctrinal heresy, perhaps I shall receive indulgent correction from the theologians. If I should misrepresent Milton, my sin would be less venial; for, without blasphemy be it spoken, my feeling for Milton is much like that of the psalmist before God: "Let us come before his presence with thanksgiving: and shew ourselves glad in him with Psalms." If I quote Milton freely, I do so because the quotations are in my judgment delightful, relevant, and convincing. If all this be idolatry, let the critics make the most of it.

Milton's poetry is quoted from The Poetical Works of John Milton, edited by H. C. Beeching; his prose, as a rule, from The Student's Milton, edited by F. A. Patterson.

Unfortunately, Rosemond Tuve's invaluable Images and Themes in Five Poems by Milton (1957) was published too late to be of service in my studies, but I should like to quote from her preface the following pregnant sentence: "Most of what the Renaissance poets learned from the Middle Ages about literary method-and this is where they learned much of what they built upon with such inventiveness and such splendor-is in him, and every sea-change that it underwent." And also this, from the chapter on Comus, explaining a detail of what she calls "the double reality of scenes and persons": "The Lady does not represent but presents virtue, and presents it in that one of its aspects most suitable to her literal self, for she does not cease to be Alice Egerton though she is equally the human spirit partially in the power of insidious evil." This criticism penetrates to the heart of truth and makes apparent the futility of some modern criticism of the Lady.

As related to my subject, Irene Samuel's recent study of the dialogue in heaven (PMLA, September, 1957) might also be mentioned. She emphasizes the importance of this dialogue, defines Milton's concept of God as the voice of Reason, Moral Law, "the Intelligence that comprehends the universe," and demonstrates the perfect dramatic and ethical propriety of this part of the epic. Here is the complete 
vindication of this dialogue; here is the conclusive refutation of all those critics who have complacently echoed Pope's quip.

Analyzing Milton's serious character and religious purpose, which in these enlightened days alienate many readers, Douglas Bush quoted Housman's lines “And malt does more than Milton can/To justify God's ways to man." This pleasantry must not pass for the truth. These lines immediately follow:

Ale, man, ale's the stuff to drink

For fellows whom it hurts to think:

Look into the pewter pot

To see the world as the world's not.

As this work is concluded and I look before and after, I recall another of Housman's poems which, it seems to me, anticipated my experience and expresses my hopes:

I hoed and trenched and weeded, And took the flowers to fair:

I brought them home unheeded; The hue was not the wear.

So up and down I sow them, For lads like me to find, When I shall lie below them, A dead man out of mind.

Some seeds the birds devour, And some the season mars, But here and there will flower The solitary stars.

In this context it scarcely becomes me to mention flowers and stars but rather to hope that some seed will fall, not by the wayside or in stony places, but into good ground and bring forth fruit in season. It is not for the sower to know or say what the harvest will be. Whatever its value, this study, with Milton at hand to bless, has for me not been altogether vain. It has brought its own sense of satisfaction, which, though not complacent, is not likely to be intimidated by the strictures of the learned as it is undaunted by a haunting nostalgia for that far country, the fields, the streams, the blue remembered hills, "The happy highways where I went/And cannot come again." There is, we are assured, another and a more hopeful prospect: there are hills eternal, in the memory and of the spirit, built by faith to stand, our own faith, not another's. Meanwhile, there is the conviction and 


\section{Prologue}

the faith that Milton is the central and supreme figure in English poetry.

To Milton's poetry the public, sophisticated and unenlightened, is, we know, indifferent. And the principal reason for this lack of interest is clear. Our age, as Humphrey Kitto, in Form and Meaning in Drama (1956), has just recently observed, "is hardly one which is instinctively attuned to religious modes of thought." This estrangement is not by any means a recent development. "Neither today nor for centuries past have we been in immediate contact with a religious culture-with its habits of mind, its natural means of expression." Properly to understand and appreciate Milton's poetry it would, therefore, be necessary to bridge the centuries, to recall and in some measure re-create the faith and the prestige of a vanished Christian civilization, in which religion was a vital force. At the outset and as a simple test one must think of the cathedral not as an attraction for tourists but as a place of worship: the ancient fane with its gray columns soaring to the dimness of its embowed roof, the delicate traceries of the organ screen, the swelling notes of the organ, "the mellow shafts of light filtered through the stained-glass windows" with their hues of emeralds and rubies and amethysts, the hushed, reverent worshipers-all these things were familiar and precious: "And storied Windows richly dight,/Casting a dimm religious light." But of course it is manifestly impossible-and in some respects undesirable-to restore the past, to return to a precritical, dogmatic metaphysic.

Adapting the language of C. J. Sisson's introduction to his New Readings in Shakespeare (1956), I may say that I have tried to "creep closer" to the minds and the speech of the Reformation and that I have resisted that absorption in our modern world which has had such a pernicious effect upon recent aesthetic criticism. With the aid of others I have done what I could do to indicate specific areas and aspects of the religious tradition which is reflected in Milton's poetry. Conscious of the inadequacy if not of the imperfection of my endeavors, I can at least say that I have not spared any labor to present "My true account, lest he returning chide."

Implicit throughout this study is the assumption that life may have spiritual values and may be interpreted spiritually and that the life of the spirit presupposes the existence of the Divine as well as the human life. "Spiritual life always implies something higher than itself towards which it is ascending." Spiritual life is not opposed to mental and physical life but transforms these to a higher plane, imparts a higher quality to them, and raises them "towards the heights, 
towards that which is beyond life, beyond nature, beyond being." In this sense life is then a symbol of the highest value and the highest good, a symbol of true being, of the final mystery.

True appreciation of Milton's poetry demands, it is clear, some insight into this fundamental truth. It demands also a rather special temperament and a kind of religious consecration along with other qualities which are extremely rare in this age in which literature frequently has no roots and criticism no tradition. In such a degenerate time Milton's audience is inevitably limited. When we figuratively ascend to the lofty spiritual and artistic heights where Milton dwells,

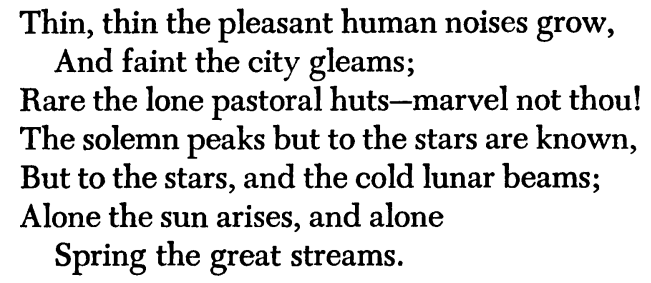

Milton was a superb craftsman, "by instinct first, and then by trained habit," as Helen Darbishire has recently said. But of course he was far more than a craftsman, isolated in a high and lonely tower. His poetry was inspired by and has in part satisfied the spiritual aspiration of humanity. Even in this skeptical age it still affords a superb view of the world sub specie aeternitatis.

For their forbearance and co-operation I thank the Department of English and the staff of the Fondren Library of The Rice Institute.

In conclusion I venture to add a more personal note. To my wife I am indebted for invaluable help and especially for her careful reading of the typescript. But, after all has been said, my greatest debt, which can never be paid, is to my mother, who revering the Word of God strove daily to be true to her Christian faith; who was "active in all that is good, industrious in all the ways in which good is to be gained"; who with patience and fortitude bore disappointment and aftliction; and who many years ago resigned "this earthy load" and passed

To where beyond these voices there is peace.

George Wesley Whiting

Houston, Texas

January, 1958

xii 